\title{
Konsepsi Kepemimpinan Astha Brata Dan Relevansinya Dengan Mata Pelajaran Sejarah Indonesia
}

\author{
Azril Azifambayunasti \\ Universitas Sebelas Maret \\ azrilazifa@student.uns.ac.id
}

\section{Article History}

received $1 / 9 / 2021$

\begin{abstract}
This study aims to analyze the Astha Brata, a classical Javanese conception of leadership and its relevance to Indonesian History subject. Through literature study, this study attempts to find the common ground between Astha Brata's conception and Indonesian History subject in the curriculum. Based on the analysis related to the conception of Astha Brata which is one of the important part of the cultural product from Hindu-Buddhist period, it is found that this conception of leadership can be integrated into material regarding the development of society during the Hindu-Buddhist period and its evidence that is still valid at the moment. The material is presented to the students of grade $X$ in first semester. The relevance of Astha Brata's conception to the curriculum of Indonesian History subject can be an appropriate means to shape the leadership character for the young generation since early through a formal learning activities.
\end{abstract}

Keywords: Astha Brata, leadership, Indonesian History, learning

\begin{abstract}
Abstrak
Kajian ini bertujuan untuk menganalisis Astha Brata, sebuah konsepsi kepemimpinan klasik Jawa dan relevansinya dengan mata pelajaran Sejarah Indonesia. Melalui studi pustaka, kajian ini berusaha mencari titik temu antara konsepsi Astha Brata dengan mata pelajaran Sejarah Indonesia dalam kurikulum. Berdasarkan analisis terkait konsepsi Astha Brata yang merupakan salah satu bagian penting dari hasil kebudayaan periode Hindu-Buddha, diperoleh hasil bahwa konsepsi kepemimpinan tersebut dapat diintegrasikan ke dalam materi mengenai perkembangan masyarakat periode kerajaan Hindu-Buddha dan bukti-buktinya yang masih berlaku hingga masa kini. Materi tersebut disajikan untuk siswa kelas $X$ semester 1 . Relevansi konsepsi Astha Brata dengan kurikulum mata pelajaran Sejarah Indonesia dapat menjadi sebuah sarana yang tepat untuk menanamkan karakter kepemimpinan bagi generasi muda sejak dini melalui kegiatan pembelajaran formal.
\end{abstract}

Kata kunci: Astha Brata, kepemimpinan, Sejarah Indonesia, pembelajaran

Social, Humanities, and Education Studies (SHEs): Conference Series p-ISSN 2620-9284 https://jurnal.uns.ac.id/shes 


\section{PENDAHULUAN}

Dalam konteks paling sederhana, individu yang berkelompok tentu memerlukan satu sosok yang lebih unggul, yang dapat mengorganisasi, melindungi, dan mewujudkan keinginan bersama mereka. Terlebih dalam konteks kebangsaan atau kenegaraan, pemimpin tidak lain merupakan nahkoda yang memikul sederet panjang kewajiban demi kesejahteraan rakyatnya. Seperti yang dikatakan Umar (2013:7-9) bahwa dalam membangun peradabannya, suatu masyarakat atau bangsa perlu sosok yang mempunyai kapasitas dan keteladanan sempurna untuk menjadi panutan. Lebih lanjut, ia mengatakan bahwa dalam konteks masa kini, sosok pemimpin tidak sama kedudukannya dengan tokoh-tokoh mitologi dan religi yang dihormati sekaligus ditakuti karena kekuatannya. Kini, sosok pemimpin seharusnya adalah ia yang dihormati lantaran kualitas, karisma, dan tanggungjawabnya.

Tentu tidak dapat dipungkiri, bahwa mempunyai sosok pemimpin yang berkualitas adalah sebuah harapan besar yang terus berusaha diwujudkan oleh masyarakat dalam suatu negara. Namun, yang kita temui di masa kini justru sebuah krisis karakter kepemimpinan. Berdasar pada pernyataan Enstein, Harsono (2010:57) mengemukakan bahwa ilmu yang indah ini hanya membawa sedikit kebahagiaan pada kita, karena di tengah derasnya arus akumulasi ilmu, pengetahuan, dan teknologi, manusia masih terus bergelut dengan krisis. Di Indonesia, menurut penuturan Syarief (2005:45), sejak otoritas pemerintah Orde Baru runtuh dan era reformasi dimulai, kita benar-benar mengalami krisis kepemimpinan. Begitu langka dan sulitnya menemukan sosok pemimpin yang mempunyai integritas intelektual dan moral. Dilansir dari laman CNN Indonesia (28 Jauari 2021), Indeks Persepsi Korupsi Indonesia pada tahun 2020 berada di skor 37 dengan peringkat 102 dari 180 negara. Posisi yang masih jauh dari harapan akan minimnya kasus korupsi. Berdasarkan skor dan peringkat tersebut, diketahui bahwa penegakan hukum mengalami peningkatan, tetapi perbaikan birokrasi yang berhubungan dengan korupsi masih stagnan. Hal tersebut kemudian selalu menimbulkan pertanyaan, bagaimana kepemimpinan yang berjalan di negara ini?

Bahkan hingga dua tahun terakhir, ditambah dengan kemunculan pandemi global COVID-19, kepemimpinan terus menjadi sorotan paling tajam di mata publik. Dalam tulisannya di laman Kompas.com, Kamil (14 Juli 2021) menyatakan bahwa kasus korupsi di Indonesia masih terus muncul di tengah pandemi. Menteri Kelautan dan Perikanan ditangkap lantaran korupsi ekspor benih lobster. Tak lama kemudian, Menteri Sosial ditetapkan sebagai tersangka dugaan kasus suap dana bantuan sosial penanganan pandemi. Ada pula Gubernur Sulawesi Selatan yang menjadi tersangka kasus suap pengadaan proyek infrastruktur dan Bupati Bandung Barat yang terlibat dugaan korupsi pengadaan barang tanggap darurat bencana pandemi. Duryat dalam tulisannya di kolom Pikiran Rakyat (22 September 2021) juga menjelaskan bahwa terkait penanganan pandemi, publik kemudian mempertanyakan kepemimpinan presiden yang banyak dinilai cenderung berada di bawah bayang-bayang pihak lain. Realitas tersebut sudah lebih dari cukup untuk menggambarkan bagaimana negara ini benar-benar mengalami krisis karakter kepemimpinan, dan siapa yang akan mencari solusinya jika bukan kita sendiri sebagai warga negara?

Untuk merespon krisis karakter kepemimpinan tersebut, tidak ada salahnya apabila kita menengok kembali ke masa lalu. Dalam perjalanan sejarah Indonesia, sosok pemimpin selalu menjadi tokoh penting dan subyek utama di banyak narasi, seperti yang dikatakan Kurniawan, dkk. (2019:38) bahwa narasi sejarah Indonesia memang didominasi oleh kisah orang-orang besar dan banyak mengeksplorasi kehidupan raja-raja. Di sisi lain, sejarah juga mewariskan sebuah konsepsi tentang bagaimana idealnya sosok pemimpin itu. Setiap masyarakat tentu mempunyai konsepsi mengenai sosok pemimpin yang layak dan ideal bagi mereka, begitu pula masyarakat Jawa pada periode Hindu-Buddha. Periode tersebut banyak mewariskan 
peninggalan kebudayaan berupa naskah sarat nilai yang masih relevan hingga kini, termasuk salah satunya yaitu konsepsi kepemimpinan Astha Brata.

Sebagai warisan budaya dan sejarah, konsepsi Astha Brata rasanya sangat perlu untuk disampaikan pada generasi muda sebagai upaya counter atas krisis kepemimpinan saat ini. Lalu, bagaimana konsepsi tersebut akan disampaikan? Apakah konsepsi kepemimpinan Astha Brata dapat ditanamkan melalui kegiatan pembelajaran formal? Oleh karena itu lah kajian kali ini akan menganalisis lebih lanjut mengenai relevansi konsepsi Astha Brata dengan mata pelajaran Sejarah Indonesia, mengingat konsepsi kepemimpinan tersebut adalah salah satu produk sejarah yang tidak hanya perlu untuk senantiasa diingat, melainkan juga penting untuk dijadikan pedoman dalam menghadapi tantangan masa kini.

\section{METODE}

Astha Brata merupakan sebuah konsepsi yang menurut Marsono (2010:28-29) memuat ajaran kepemimpinan ideal dan masih relevan lintas zaman. Konsepsi tersebut termuat dalam cerita Ramayana di berbagai naskah kuno yang pernah ada di Jawa, baik yang berasal dari abad ke-9 maupun awal abad ke-20. Konsepsi tersebut memaparkan bahwa sosok pemimpin ideal adalah ia yang mempunyai karakter mengacu pada delapan sifat dewa, yang dalam perkembangannya kemudian berubah acuannya menjadi delapan sifat unsur alam semesta.

Sementara itu, pembelajaran sejarah adalah penyampaian secara formal terkait studi tentang manusia di masa lampau. Pembelajaran sejarah tidak hanya sekadar bertugas menyampaikan informasi dari masa lampau, tetapi menurut Kochhar (2008:35), ia juga perlu menjadikan peserta didik mampu mengambil nilai dari masa lampau tersebut guna direfleksikan di masa kini. Dengan pembelajaran sejarah, masyarakat diharapkan memiliki wawasan, kesadaran, dan nilai-nilai yang berkenaan dengan bangsanya, atau dalam arti lain, pembelajaran sejarah mengemban tugas pembentukan karakter dan penanaman nilai budaya (Zahro, dkk., 2017:2-3).

Pembahasan ini dikaji menggunakan metode studi pustaka. Metode tersebut dilakukan dengan memanfaatkan sumber pustaka yang telah tersedia untuk memperoleh data yang diperlukan. Menurut Zed (2004:4-5), metode studi pustaka mempunyai empat ciri, antara lain: (1) peneliti berhadapan langsung dengan teks; (2) data pustaka bersifat siap pakai; (3) data pustaka umumnya merupakan sumber sekunder; dan (4) kondisi data pustaka tidak dibatasi ruang dan waktu. Dalam pembahasan ini, pustaka yang digunakan adalah buku dan artikel jurnal terkait konsepsi Astha Brata dan pembelajaran sejarah serta dokumen kurikulum mata pelajaran Sejarah Indonesia. Setelah mengumpulkan pustaka sesuai dengan kebutuhan tema, penulis kemudian membaca dan menuliskan pernyataan-pernyataan yang dianggap dapat membangun narasi sesuai dengan pembahasan.

\section{HASIL DAN PEMBAHASAN Astha Brata: Konsepsi Kepemimpinan Jawa}

Astha Brata, secara etimologis dapat diartikan sebagai delapan perilaku yang merujuk pada perilaku ideal seorang pemimpin. Menurut Soebadio, dkk. (1997:1), Astha Brata merupakan konsepsi yang memuat ajaran moral-didaktik terkait kepemimpinan, dan umumnya ditemukan dalam rangkaian kisah Rama. Kisah Rama atau Ramayana adalah epik dari negeri India sebagai bagian dari ajaran agama Hindu. Menurut Poesponegoro dan Notosusanto (2010:27), hubungan dagang antara India dan wilayah-wilayah di Kepulauan Nusantara yang telah berlangsung lama menyebabkan masuknya pengaruh India, termasuk ajaran agama Hindu, yang dalam perkembangannya kemudian bercampur dengan budaya lokal. Pengaruh tersebut tidak terbatas pada ranah agama, tetapi juga politik, dimana masyarakat Kepulauan 
Nusantara kemudian mengenal sistem pemerintahan monarki yang dipimpin seseorang dengan gelar raja, yang menurut Kurniawan (2019:198) umumnya dikultuskan sebagai titisan dewa atau wakil Tuhan, sehingga ia mempunyai tanggungjawab besar dalam menciptakan keharmonisan antara manusia, alam, dan Tuhan.

Kisah Ramayana telah disadur oleh pujangga Jawa sejak akhir abad ke-9 ketika Kerajaan Hindu terbesar berpusat di Jawa Tengah dengan lebih mengacu pada Ramayana versi Bhattikawya (Poerbatjaraka dalam Tedjowirawan, 2012:4-5). Dalam rangkaian kisah itu lah konsepsi Astha Brata dimuat, baik dalam saduran versi abad ke-9 yang dikenal dengan Ramayana Kakawin Jawa Kuno maupun Serat Rama Jarwa Macapat Jawa Baru yang digubah Yasadipura II pada tahun 1882. Selain itu, konsepsi Astha Brata juga dapat ditemui dalam Serat Nitisruti, Babad Sangkala, Serat Partawigena, lakon wayang Wahyu Makutha Rama, dan diorama gambar wayang di Museum Purnabakti Taman Mini Indonesia Indah (Marsono, 2010:28). Dalam kajian ini, konsepsi Astha Brata yang dibahas terbatas pada konsepsi yang termuat dalam Serat Rama Jarwa Macapat Jawa Baru, kisah Ramayana yang kembali digubah oleh Yasadipura II ketika elit kerajaan Jawa pada masa itu hanya mempunyai sedikit peluang untuk melakukan manuver politik karena kuatnya kekuasaan kolonial Belanda (Ricklefs, 2001:273).

Serat Rama disebut Soebadio, dkk. (1997:31-32) sebagai sumbangan besar dalam khasanan sastra Jawa karena telah mengalihbahasakan Ramayana Kakawin yang berbahasa Jawa Kuno ke dalam Bahasa Jawa Baru. Serat Rama yang memuat kisah hidup Prabu Rama beserta ajarannya terkait kebijaksanaan dalam hidup dan menjalankan pemerintahan itu berjumlah 596 halaman dan terdiri dari 90 pupuh. Konsepsi Astha Brata yang menurut As'ad, dkk. (2011:230) berisi delapan ajaran perilaku pemimpin mengacu pada sifat dewa-dewa alam, tertuang pada pupuh LXXVII Pangkur dengan jumlah bait 35 buah (Yasadipura dalam Marsono, 2010:30). Pada pupuh tersebut, diceritakan bahwa setelah Rahwana gugur dalam pertempuran melawan Rama, adiknya yang bernama Wibisana begitu sedih dan terpukul. Rama kemudian mengingatkannya untuk tidak terlalu larut dalam kesedihan karena Rahwana telah gugur sebagai ksatria hebat. Rama juga mengangkat Wibisana sebagai raja baru Alengka serta menyarankan supaya ia sebagai raja mampu memimpin para raksasa dan membenahi tingkah laku mereka menjadi lebih baik. Saat itu lah Rama kemudian menyampaikan bahwa sebagai raja, Wibisana harus berpedoman pada delapan dewa supaya tidak terjadi kecacatan dalam kepemimpinannya. Delapan dewa tersebut antara lain yaitu Dewa Indra, Dewa Surya, Dewa Bayu, Dewa Kuwera, Dewa Baruna, Dewa Yama, Dewa Candra, dan Dewa Brama (Soebadio, dkk., 1997:66-67).

Dalam konsepsi Astha Brata, delapan dewa tersebut masing-masing mempunyai sifat yang perlu diterapkan ke dalam perilaku seorang pemimpin. Berikut adalah uraian mengenai delapan sifat dewa alam yang mencerminkan karakter permimpin ideal:

1. Dewa Indra, dewa hujan yang menyediakan segala hal yang diperlukan oleh bumi dan memberikan kesejahteraan secara merata tanpa membedakan masyarakat besar atau kecil. Dengan menurukan hujan, ia memberikan sumber kehidupan dan menjaga ketentraman dunia (Marsono, 2010:30-32). Dengan demikian, seorang pemimpin harus senantiasa menyejahterakan rakyatnya secara adil.

2. Dewa Surya, dewa matahari dengan sifat sabar, tidak tergesa-gesa, welas asih, dan bijaksana. la memberikan penerangan secara terus menerus sehingga membuat banyak tanaman menjadi subur (Marsono, 2010:35-38). Dengan 
demikian, seorang pemimpin harus senantiasa memberikan sabar, bijaksana, welas asih, dan selalu memberikan penerangan bagi rakyatnya.

3. Dewa Bayu, dewa angin yang mampu masuk ke segala penjuru dengan mudah, sehingga ia dapat mengetahui segala perilaku baik maupun buruk manusia (Marsono, 2010:40-43). Dengan demikian, seorang pemimpin harus senantiasa melihat langsung rakyatnya ke lapangan supaya ia benar-benar mengetahui secara langsung bagaimana kondisi yang ada.

4. Dewa Kuwera, dewa bumi atau dewa kekayaan yang senantiasa ulet demi memenuhi kesejahteraan masyarakat. la selalu mencukupi kebutuhan pangan masyarakat secara adil sesuai dengan usaha masing-masing (Marsono, 2010:4346). Dengan demikian, seorang pemimpin harus senantiasa adil memberikan hak rakyatnya demi terwujudnya kesejahteraan.

5. Dewa Baruna, dewa samudera yang menampung seluruh air di muka bumi dan segala yang mengalir di dalamnya. la sabar dan berwawasan luas seluas samudera (Marsono, 2010:46-48). Dengan demikian, seorang pemimpin harus mempunyai wawasan luas sehingga mampu dengan bijak menerima segala realita baik maupun buruk.

6. Dewa Yama, dewa kematian yang membasmi segala perbuatan buruk. la bertindak tegas terhadap segala bentuk kejahatan dan kekacauan tanpa pandang bulu (Marsono, 2010:32-35). Dengan demikian, seorang pemimpin harus bertindak tegas terhadap segala bentuk kejahatan yang merugikan rakyatnya dengan adil.

7. Dewa Candra, dewa bulan yang lembut, ramah, sabar, dan pemaaf sehingga begitu dihormati (Marsono, 2010:38-40). Dengan demikian, seorang pemimpin harus memerintah dengan ramah dan bersahabat supaya disegani oleh masyarakat.

8. Dewa Brama, dewa api yang memberikan cahaya dalam kegelapan, tetapi juga dapat memusnahkan segala hal (Marsono, 2010:48-50). Dengan demikian, pemimpin harus mampu menolong rakyatnya yang kesusahan sekaligus tegas membasmi kejahatan.

Dalam perkembangannya, delapan pedoman perilaku pemimpin dalam konsepsi Astha Brata kemudian disebut tidak lagi mengacu pada sifat dewa, tetapi unsur-unsur alam semesta. Seperti yang dikatakan Tedjawirawan dalam Suhari (2017:190) bahwa acuan perilaku ideal pemimpin dalam konsepsi Astha Brata di masa kini lebih mengarah pada delapan sifat yang berasal dari unsur alam semesta, yang antara lain yaitu bumi, air, angin, samudera, bulan, matahari, api, dan bintang. Namun, ajaran kepemimpinan di dalamnya pada intinya tetap sama.

\section{Pembelajaran Sejarah}

Istilah pembelajaran menurut Suardi (2018:7) adalah proses interaksi yang terjadi pada suatu lingkungan belajar dengan tujuan membentuk sikap peserta serta memberikan ilmu dan pengetahuan. Mulyasa $(2005: 110)$ juga menyatakan bahwa pembelajaran adalah suatu proses interaksi yang akan membawa perubahan pada perilaku menuju ke arah yang lebih baik. Kemudian, Basri dan Sumargono (2018:71) menjelaskan bahwa dalam proses pembelajaran akan terjadi interaksi yang menyebabkan terjadinya transfer pengetahuan. Dengan demikian, peserta didik yang awalnya tidak tahu menjadi tahu, sehingga mereka akan menuju ke titik yang lebih baik. 
Sejarah sendiri memiliki pengertian yang begitu luas dan beragam. Burckhardt dalam Kochhar (2008:2) mengartikan sejarah sebagai catatan mengenai masa demi masa yang pernah terjadi, yang ditemukan dan dianggap dapat memberikan manfaat bagi generasi yang akan datang. Hampir senada dengan Burckhardt, Kuntowijoyo (1995:14) mendefinisikan sejarah sebagai suatu rekonstruksi atas masa lalu yang tidak hanya berguna untuk kepentingan masa lalu, tetapi juga berguna untuk kepentingan di masa yang akan datang. Dengan demikian, pembelajaran sejarah dapat diartikan sebagai proses transfer pengetahuan kesejarahan dengan tujuan memberikan pengetahuan mengenai masa lalu beserta pelajaran yang dapat diambil untuk pedoman masa kini dan masa depan.

Kochhar (2008:67) menyebut pembelajaran sejarah sebagai kajian ilmiah tentang manusia dan berbagai kesuksesan serta kegagalannya, juga meliputi aspek kehidupannya seperti politik, ekonomi, sosial, budaya, seni, dan agama. Pembelajaran sejarah pada umumnya diimplementasikan pada jenjang sekolah menengah, seperti Sekolah Menengah Atas (SMA)/Madrasah Aliyah (MA) dan Sekolah Menengah Kejuruan (SMK)/Madrasah Aliyah Kejuruan (MAK) melalui mata pelajaran Sejarah. Secara umum, Kochhar (2008:38-41) menjelaskan tujuan pembelajaran sejarah sebagai berikut: (1) memberikan pemahaman tentang tahap-tahap perkembangan masyarakat; (2) menumbuhkan kebanggan terhadap budaya yang telah dicapai masyarakat; (3) menumbuhkan pemahaman kritis tentang masa lalu; (4) mengembangkan penghargaan terhadap budaya yang beragam dan perkembangan yang dilaluinya; (5) mengembangkan kemampuan mengkaji masalah kontemporer dalam perspektif sejarah; (6) memajukan studi tentang sejarah; (7) mengembangkan pemahaman tentang proses perubahan; dan (8) mengembangkan kesadaran pentingnya memelihara monumen-monumen sejarah. Dengan demikian, pembelajaran sejarah pada hakikatnya bukan hanya proses untuk mengetahui masa lalu, tetapi juga merupakan sarana untuk melestarikan masa lalu beserta nilai-nilainya, supaya masyarakat mempunyai pegangan dalam menjalani hidup di masa kini dan menghadapi masa depan.

Dalam Kurikulum 2013, mata pelajaran Sejarah dikelompokkan menjadi Sejarah Indonesia yang termasuk ke dalam kelompok mata pelajaran wajib dan Sejarah yang termasuk ke dalam kelompok mata pelajaran peminatan. Untuk mata pelajaran Sejarah Indonesia, seluruh siswa baik SMA/MA wajib menempuhnya sejak di kelas XI sampai dengan kelas XII. Sementara itu, siswa SMK/MAK wajib menempuh mata pelajaran Sejarah Indonesia di kelas $X$ saja. Kemudian, mata pelajaran Sejarah hanya wajib ditempuh oleh siswa SMA/MA yang mengambil penjurusan IImu-IImu Sosial (IIS). Untuk porsi jam pelajaran, mata pelajaran Sejarah Indonesia mendapatkan porsi 2 jam di SMA/MA dan 3 jam di SMK/MAK setiap minggunya, sedangkan mata pelajaran Sejarah mendapatkan porsi 4 jam bagi siswa jurusan IIS di SMA/MA.

Berdasarkan Buku Teks Sejarah Indonesia Untuk SMA/MA (2017), dalam Kurikulum 2013, pembelajaran sejarah dilakukan secara kontekstual dimana siswa diharapkan dapat melihat sejarah dalam kehidupan sehari-hari dengan cara melakukan pengamatan terhadap kondisi sosial-budaya dan peninggalan-peninggalan sejarah di sekitar. Dari fenomena-fenomena yang telah ditemukan, siswa akan dapat mengaitkan hal tersebut dengan berbagai peristiwa di masa lalu. Kuntowijoyo (1995:20) juga menyebutkan bahwa sejarah mempunyai fungsi pendidikan moral, sehingga peserta didik tidak hanya mampu mengetahui kapan, dimana, mengapa, dan bagaimana peristiwa-peristiwa sejarah terjadi, tetapi mereka juga harus mendapatkan manfaat yang nyata dari pembelajaran tersebut. Dengan demikian, tujuan dari pembelajaran sejarah dalam Kurikulum 2013 tidak hanya sekadar mengetahui fakta-fakta sejarah 
yang ada, tetapi juga memahami makna dan mengambil pelajaran yang dapat digunakan di masa kini.

Pada abad ke-21, Indonesia menghadapi berbagai macam tantangan, baik secara lokal maupun global. Dalam ranah lokal, Indonesia sangat rawan terhadap ancaman disintegrasi dan berbagai fenomena lainnya. Sementara itu, dalam ranah global, ancaman tersebut yaitu berbagai ide seperti liberalisme, sekulerisme, materialisme, hedonisme, dan konsumerisme yang memberikan pengaruh cukup besar pada pola pikir dan perilaku masyarakat. Ironisnya lagi, kebanyakan masyarakat pada saat ini masih enggan untuk mempelajari masa lalu dan mengambil pelajaran darinya. Oleh karena itu, pembelajaran sejarah dalam Kurikulum 2013 dirancang sebagai proses pembelajaran yang kritis dan komprehensif, serta memberikan keterampilan dan cara berpikir sejarah, membentuk kesadaran, menumbuhkembangkan nilai-nilai kebangsaan, mengembangkan inspirasi, dan mengaitkan peristiwa-peristiwa lokal dengan peristiwa nasional (Silabus Mata Pelajaran Sejarah Indonesia Untuk SMA/MA, 2016).

Lebih lanjut, dalam Silabus Mata Pelajaran Sejarah Indonesia Untuk SMA/MA (2016) disebutkan bahwa pembelajaran sejarah dirancang untuk menyampaikan bahwa peristiwa-peristiwa sejarah yang pernah terjadi di Indonesia juga dapat dijadikan sebagai landasan dalam membangun kehidupan berbangsa dan bernegara pada masa kini dan masa yang akan datang. Senada dengan pembelajaran sejarah yang telah dirancang dalam Kurikulum 2013, Kurniawan (2013:36) juga menegaskan bahwa pembelajaran sejarah tidak boleh hanya terpaku pada fakta mengenai peristiwaperistiwa masa lampau. Hal tersebut justru akan menyebabkan peserta didik tidak belajar, melainkan hanya menghafalkan banyak materi. Pembelajaran sejarah seharusnya dapat menanamkan nilai-nilai dan kesadaran sejarah serta memberikan kesempatan kepada peserta didik untuk menggali makna dari materi-materi yang telah disampaikan oleh guru. Oleh karena itu, sudah semestinya pembelajaran sejarah mengakomodasi materi yang dapat menyampaikan nilai yang relevan dengan konteks masa kini.

\section{Konsepsi Astha Brata Dalam Mata Pelajaran Sejarah Indonesia}

Konsepsi Astha Brata memuat ajaran mengenai sifat-sifat yang sudah sepatutnya menjadi acuan perilaku yang mencerminkan karakter kepemimpinan. Sebuah konsepsi sarat nilai dari zaman klasik, yang mungkin hampir tenggelam dan terlupakan di era modern, padahal di sisi lain sangat diperlukan mengingat krisis kepemimpinan yang masih terus mengakar dalam sistem pemerintahan. Dengan demikian, konsepsi kepemimpinan tersebut seharusnya ditanamkan sejak dini sebagai upaya counter atas krisis dan usaha membentuk karakter kepemimpinan dalam diri generasi muda.

Konsepsi Astha Brata adalah sebuah warisan sejarah. Sebagai bagian dari kisah Ramayana, epos ajaran Hindu dari India yang kemudian digubah oleh para pujangga lokal, konsepsi tersebut berkaitan erat dengan hasil kebudayaan periode HinduBuddha yang pernah berjaya dalam perjalanan sejarah bangsa Indonesia. Konsepsi tersebut mewakili pandangan dan prinsip masyarakat Hindu Jawa pada masa itu, sekaligus menyampaikan nilai penting yang masih sangat relevan hingga masa kini. Oleh karena itu, konsepsi Astha Brata seharusnya dapat disampaikan dalam pembelajaran sejarah melalui mata pelajaran Sejarah Indonesia.

Sebagaimana tujuan dari pembelajaran sejarah untuk tidak sekadar menyampaikan informasi dari masa lalu melainkan juga perlu menanamkan nilai-nilai yang kontekstual, maka konsepsi Astha Brata dapat menjadi materi ajar pelengkap atau suplemen untuk 
menyampaikan dan menanamkan karakter kepemimpinan ke dalam diri peserta didik. Mengingat dalam Kurikulum 2013 kini pembelajaran sejarah dikelompokkan ke dalam dua mata pelajaran wajib dan peminatan, konsepsi Astha Brata rasanya lebih relevan untuk diintegrasikan ke dalam materi di mata pelajaran Sejarah Indonesia kelompok wajib. Dengan demikian, seluruh siswa dari berbagai jurusan di SMA/MA, termasuk juga siswa SMK/MAK akan dapat memperoleh pembelajaran terkait konsepsi Astha Brata yang merupakan salah satu warisan kebudayaan dari periode Hindu-Buddha.

Dalam kurikulum mata pelajaran Sejarah Indonesia, materi ajar yang disampaikan di kelas $X$ meliputi peradaban awal Kepulaua Indonesia, periode Hindu-Buddha, dan periode Islam. Kemudian, materi kelas XI meliputi kolonialisme dan imperialisme termasuk juga perlawanan yang muncul serta dampaknya, Sumpah Pemuda, pendudukan Jepang, kemerdekaan, dan revolusi mempertahankan kemerdekaan. Sementara itu, di kelas XII, materi yang diajarkan antara lain yaitu perjuangan menghadapi ancaman disintegrasi, sistem politik dan ekonomi demokrasi parlementer, demokrasi terpimpin, orde baru, dan reformasi, serta Indonesia dalam panggung dunia (Buku Teks Sejarah Indonesia Untuk SMA/MA, 2017). Berdasarkan uraian mengenai cakupan materi tersebut, dapat ditarik kesimpulan bahwa konsepsi Astha Brata yang termuat dalam rangkaian kisah Ramayana dapat diintegrasikan ke dalam materi seputar periode Hindu-Buddha di kelas X.

Materi mengenai periode Hindu-Buddha disajikan di bab II dalam buku teks mata pelajaran Sejarah Indonesia dengan judul Pedagang, Penguasa, dan Pujangga Pada Masa Klasik (Hindu-Buddha). Pembahasan dalam materi tersebut mencakup proses masuknya agama Hindu-Buddha serta perkembangan masyarakat, pemerintahan, dan budaya pada masa itu. Materi tersebut terinci ke dalam dua Kompetensi Dasar (KD) pada silabus mata pelajaran Sejarah Indonesia, yaitu KD 3.5 Menganalisis berbagai teori tentang proses masuknya agama dan kebudayaan Hindu-Buddha ke Indonesia, serta KD 3.6 Menganalisis perkembangan kehidupan masyarakat, pemerintahan, dan budaya pada masa kerajaan-kerajaan Hindu-Buddha di Indonesia serta menunjukan contoh bukti-bukti yang masih berlaku pada kehidupan masyarakat Indonesia masa kini (Buku Teks Sejarah Indonesia Untuk SMA/MA, 2017). Dengan demikian, konsepsi Astha Brata dapat menjadi materi pelengkap atau suplemen yang mengacu pada KD 3.6 karena merupakan hasil kebudayaan periode Hindu-Buddha, yang nilai-nilainya masi relevan dalam kehidupan masyarakat masa kini.

Sebagai materi pelengkap atau suplemen, konsepsi Astha Brata dapat menjadi materi tambahan yang melengkapi pembahasan mengenai perkembangan kehidupan masyarakat dalam bidang kebudayaan pada periode Hindu-Buddha secara umum. Dalam Peraturan Menteri Pendidikan Nasional Nomor 2 (2008), materi dalam buku teks dapat dilengkapi dengan materi dari buku lain, seperti buku referensi dan buku pengayaan. Kemudian, Permanasari (2015:2058) mengungkapkan bahwa materi suplemen umumnya berfungsi untuk menambah dan memperkaya pengetahuan siswa. Apabila materi tersebut memuat nilai-nilai yang sarat manfaat bagi masyarakat masa kini, maka keberadaan materi suplemen akan memaksimalkan perwujudan tujuan pembelajaran sejarah. Oleh karena itu, di era yang tengah diguncang krisis kepemimpinan ini, tidak ada salahnya jika mata pelajaran Sejarah Indonesia mengakomodasi penyampaian dan penanaman nilai karakter kepemimpinan yang termuat dalam konsepsi Astha Brata. Dengan demikian, generasi muda akan lebih mengenal dan memiliki awareness terkait bagaimana sosok pemimpin ideal seharusnya mampu membawa kesejahteraan bagi masyarakatnya di tengah arus global perkembangan ilmu pengetahuan dan teknologi. 


\section{SIMPULAN}

Perihal kepemimpinan tengah mengalami krisis yang memerlukan respon urgent dewasa ini. Pemimpin bukan lagi sosok yang dinilai memiliki kualitas dan integritas dalam melaksanakan amanat jabatannya. Sebagai respon atas hal tersebut, pengkajian kembali atas konsepsi klasik mengenai karakter kepemimpinan tentu perlu untuk dilakukan. Oleh karena itu, konsepsi Astha Brata yang memuat ajaran tentang delapan sifat dewa/unsur alam sebagai pedoman perilaku pemimpin, sangat perlu disampaikan dan ditanamkan pada generasi muda, salah satunya melalui pembelajaran sejarah. Konsepsi kepemimpinan tersebut dapat menjadi materi suplemen yang terintegrasi pada materi seputar periode Hindu-Buddha untuk siswa SMA sederajat.

\section{DAFTAR PUSTAKA}

As'ad, M., dkk. (2011). "Studi Eksplorasi Konstrak Kepemimpinan Model Jawa: Asta Brata". Jurnal Psikologi, 38 (2) 228-239.

Basri, M. \& Sumargono. (2018). Media Pembelajaran Sejarah. Yogyakarta: Graha llmu. CNN Indonesia. (28 Januari 2021). Ranking Indeks Korupsi Indonesia Merosot, Urutan 102 dari $180 . \quad$ Retrieved from https://www.cnnindonesia.com/nasional/20210128134510-12-599524/rankingindeks-korupsi-indonesia-merosot-urutan-102-dari-180, on 25th September 2021.

Duryat, M. (22 September 2021). Pemimpin Perlu Jabatan? Menyoal Pandemi Covid$19 \mathrm{di}$ Indonesia. Retrieved from https://www.pikiran-rakyat.com/kolom/pr012648654/pemimpin-perlu-jabatan-menyoal-pandemi-covid-19-di-indonesia, on 25th September 2021.

Harsono, A. (2010). "Paradigma 'Kepemimpinan Ketua' Dan Kelemahannya”. Jurnal Makara: Sosial dan Humaniora, 14 (1) 56-64.

Kamil, I. (14 Juli 2021). Pandemi Pun Tak Hentikan Munculnya Kasus Korupsi. Retrieved from https://nasional.kompas.com/read/2021/07/14/19255121/pandemi-pun-takhentikan-munculnya-kasus-korupsi?page=all, on 25th September 2021.

Kochhar, S. K. (2008). Teaching of History. Jakarta: PT Grasindo.

Kuntowijoyo. (1995). Pengantar Ilmu Sejarah. Yogyakarta: Tiara Wacana.

Kurniawan, A. F. (2019). "Falsafah Kepemimpinan Pendidikan (Hasta Brata sebagai Basis Kepemimpinan Pendidikan)". Jurnal Ri'ayah, 4 (2) 194-207.

Kurniawan, H. (2013). "Penanaman Karakter Melalui Pembelajaran Sejarah dengan Paradigma Konstruktivistik dalam Kurikulum 2013". Socia: Jurnal-Jurnal IImu Sosial, 10 (1) 35-44.

Kurniawan, G. F., dkk. (2019). "Dominasi Orang-Orang Besar Dalam Sejarah Indonesia: Kritik Politik Historiografi dan Politik Ingatan". Jurnal Sejarah Citra Lekha, 4(1) 36-52.

Marsono. (2010). "Amanat Kepemimpinan Ideal Asthabrata Dalam Serat Rama Yasadipura (Analisis Intertekstual)". Jurnal Jumantara, 1 (2) 25-52.

Mulyasa, E. (2005). Menjadi Guru Profesional: Menciptakan Pembelajaran Kreatif dan Menyenangkan. Bandung: Remaja Rosdakarya.

Peraturan Menteri Pendidikan Nasional Nomor 2. (2008). Buku. Jakarta: Kementerian Pendidikan Nasional Republik Indonesia.

Permanasari, L. I. (2015). "Pengembangan Buku Suplemen Berorientasi Pendekatan Kontekstual Untuk Meningkatkan Keterampilan Menulis Laporan Siswa Kelas V SD”. Jurnal Penelitian Pendidikan Guru Sekolah Dasar.,3 (2) 2057-2066.

Poesponegoro, M. D., \& Notosusanto, N. (2010). Sejarah Nasional Indonesia II: Zaman Kuno. Jakarta: Balai Pustaka. 
SHEs: Conference Series 5 (1) (2022) 72- 81

Ricklefs, M, C. (2001). Sejarah Indonesia Modern 1200-2004. Jakarta: PT Serambi IImu Semesta.

Sejarah Indonesia. (2017). Jakarta: Kementerian Pendidikan dan Kebudayaan.

Silabus Mata Pelajaran Sekolah Menengah Atas/Sekolah Menengah Kejuruan/Madrasah Aliyah/Madrasah Aliyah Kejuruan: Mata Pelajaran Sejarah Indonesia. 2016. Jakarta: Kementerian Pendidikan dan Kebudayaan.

Soebadio, dkk. (1997). Kajian Astabrata: Pendahuluan dan Teks Jilid I. Jakarta: CV Putra Sejati Raya.

Suardi, M. (2018). Belajar dan Pembelajaran. Yogyakarta: Deepublish.

Suhari. (2017). "Menggali Nilai-Nilai Karakter Bangsa Dalam Ajaran Hastabrata Lakon Pewayangan Makutharama". Jurnal Buana Pendidikan, 13 (24) 187-198.

Tedjowirawan, A. (2012). "Menelusuri Jejak Cerita Rama dalam Serat Pustakaraja Karya Pujangga R.Ng. Ranggawarsita". Jurnal Jumantara, 3 (1) 1-43.

Umar, B. W. (2013). "Krisis Kepemimpinan". Jurnal Legalitas, 4 (1) 7-21.

Zahro, M., dkk. (2017). "The Implementation Of The Character Education In History Teaching". Jurnal Historica, 1 (1) 1-11.

Zed, M. (2004). Metode Penelitian Kepustakaan. Yogyakarta: Yayasan Obor Indonesia. 